J. Amer. Soc. Hort. Sci. 116(4):651-654. 1991.

\title{
Soil Disinfection and Monoammonium Phosphate Fertilization Increase Precocity of Apples on Replant Problem Soils
}

\author{
G.H. Neilsen' and J. Yorston ${ }^{2}$ \\ Agriculture Canada Research Station, Summerland, BC VOH 1Z0, Canada
}

Additional index words. Malus domestica, formalin, dazomet, mancozeb, replant disorder

\begin{abstract}
In an apple (Malus domestica Borkh.) orchard with a severe replant problem, tree size was increased by the 2nd year and number of fruit by the 3rd year by treating the planting hole soil with formalin or mancozeb plus monoammonium phosphate (MAP) fertilizer. Growth increases were evident each year for 4 years only for the MAP + formalin treatment. In a second orchard, with a less severe replant problem, planting-hole treatment with formalin or dazomet + MAP increased tree size by year 2. Number of fruit in year 2 was increased by formalin and mancozeb + MAP treatments, although this effect persisted in year 3 only for mancozeb + MAP. Leaf P concentrations were increased to high values in the first year by MAP fertilization but declined in subsequent years. Leaf Mn concentration also increased in one orchard, a consequence of fertilizer-induced acidification of planting hole soil and Mn uptake from the fungicide mancozeb. Chemical names used: tetrahydro-3,5-dimethyl-2 $H$-1,3,5-thiadiazine-2-thione (dazomet); $37 \%$ aqueous solution formaldehyde (formalin); $\mathrm{Zn}$, Mn ethylene dithiocarbamate (mancozeb).
\end{abstract}

Poor growth and delayed fruit production of apple trees planted in old orchards is an important problem in all major applegrowing regions of the world (Traquair, 1984; Yadava and Doud, 1980). Overcoming replant disorders is critical for the successful establishment of high-density orchards to achieve the desirable acceleration of yield normally associated with these plantings. Replant problems have been attributed to physical, chemical and, particularly, biological disorders of the soil (Traquair, 1984), with a range of successful treatments in various fruit-growing areas reflecting this diversity. For example, preplant soil disinfection with biocides, including formalin (Covey et al., 1984; Sewell and White, 1979), trichloronitromethane (chloropicrin) (Hoestra, 1968), and methyl bromide (Koch et al., 1980), improved the growth of seedlings in greenhouse tests and young trees in orchard trials, despite a concern that broad-spectrum biocides may destroy potentially beneficial mycorrhizal fungi (Traquair, 1984). Toxicities, caused by excess Mn, Al (Hoyt and Neilsen, 1985), or As (Benson, 1976), and nutrient deficiencies, including K (Merwin and Stiles, 1989), have been cited as causes of poor growth of apple. In British Columbia, Slykhuis and Li (1985) demonstrated in greenhouse tests that the growth of apple seedlings in soil from old orchards was generally increased by preplanning treatments with specific fumigants, fungicides, or MAP fertilizer. The greatest benefits resulted from the use of both MAP and a fumigant or fungicide. Similar responses were demonstrated in orchard trials in which sites were treated before transplanting young trees (J.T. Slykhuis, personal communication).

The present study was undertaken to further test the effects of combinations of soil disinfection and MAP fertilization on the initial growth, yield, and nutrition of apple trees transplanted into soil in orchards exhibiting differing severity of replant problems.

Received for publication 12 Oct. 1990. Contribution no. 765 of Agriculture Canada, Research Station, Summerland, B.C. Technical assistance by Bill Hedges and George Carter, British Columbia Ministry of Agriculture and Fisheries, is gratefully acknowledged. The cost of publishing this paper was defrayed in part by the payment of page charges. Under postal regulations, this paper therefore must be hereby marked advertisement solely to indicate this fact.

${ }^{1}$ Research Scientist.

${ }^{2}$ Deceased, Plant Pathologist, British Columbia Ministry of Agriculture and Fisheries.

\section{Materials and Methods}

Two experimental sites were selected on the basis of a greenhouse bioassay test with apple seedlings that indicated marked growth responses to various combinations of MAP and soil disinfectants. Average seedling height after 10 weeks was increased in orchard 1 by treatments including (all per liter) 1.5 g MAP (248\%), 0.33 g mancozeb plus 1.5 g MAP (231\%), and $14 \mathrm{ml}$ formalin plus $1.5 \mathrm{~g}$ MAP (479\%) (data not shown). Growth increases in orchard 2 were also large for treatments including MAP $(165 \%)$ and combinations of $0.33 \mathrm{~g}$ dazomet/liter $(265 \%)$, mancozeb (284\%), and formalin (288\%), all with MAP fertilization. Apple seedling bioassay tests were developed in the Netherlands (Hoestra, 1968) to indicate soils with "apple replant disease". In England, soil fumigation for apple replant disease is recommended if the ratio of average seedling height after 12 weeks of greenhouse growth relative to that of nonfumigated checks exceeds $150 \%$ (dwarfing rootstock) or $200 \%$ (other rootstock) (Sewell et al., 1988). Although tests in England eliminate nutritional constraints by periodic nutrient solution additions to test seedlings, use of the English growth criterion would lead to the application of all of the above treatments in our field situations. Both sites used by us had been planted in apples that were removed the year before spring replanting. Orchard 1, for which tests indicated a severe replant problem, was located on an Oyama sandy loam soil (Kelley and Spilsbury, 1949) with an average $\mathrm{pH}$ at a depth of 0 to $15 \mathrm{~cm}$ of 5.8 (1 soil :2 water) and a high $0.25 \mathrm{M} \mathrm{HOAc}+0.015 \mathrm{M}$ $\mathrm{NH}_{4} \mathrm{~F}$ extractable $\mathrm{P}$ concentration of $247 \mu \mathrm{g} \cdot \mathrm{g}^{-1}$. Orchard 2, with a less severe replant problem, was located on a Kalmalka loam soil with a $\mathrm{pH}$ averaging 6.8 and a moderate extractable $\mathrm{P}$ concentration of $56 \mu \mathrm{g} \cdot \mathrm{g}^{-1}$.

In orchard 1, 'McIntosh' apples on M.4 rootstock were replanted in Spring 1986 at a spacing of $2.74 \mathrm{~m}$ within the row by $4.56 \mathrm{~m}$ between the rows. A randomized complete block experimental design involving four planting-hole treatments, each with 10 single-tree replicates, was established in a single midorchard row. Treatments included application of 1) $16.5 \mathrm{~g} \mathrm{~N}$ applied as $48.5 \mathrm{~g} \mathrm{NH}_{4} \mathrm{NO}_{3}$ (control trees), 2) $16.5 \mathrm{~g} \mathrm{~N}$ and 36 g P applied as $150 \mathrm{~g}$ MAP, 3) $200 \mathrm{ml}$ formalin (37\% aqueous solution of formaldehyde) plus $150 \mathrm{~g}$ MAP, and 4) $30 \mathrm{~g}$ mancozeb (Zn, Mn ethylene bisdithiocarbamate) also with $150 \mathrm{~g}$ MAP. All fertilizer and the mancozeb treatments were uni- 
formly mixed in $\approx 125$ liters of planting hole soil for the 17 Apr. planting. The formalin treatment was applied 24 Mar. in 15 liters of water, with half the volume applied to the bottom of the hole and the other half applied to the half-filled hole, which was completely refilled before wetting with an additional 15 liters of water. No formaldehyde odor was detected on 9 Apr. when these sites were redug by hand in preparation for planting on 17 Apr.

Orchard 2 was replanted in Spring 1987 with 'Empire' apple on M.26 rootstock at a spacing of $3 \mathrm{~m}$ within row by $4 \mathrm{~m}$ between row. The randomized complete block experimental design included five planting-hole treatments, each with four, fourtree replicates, located in 20 orchard rows. Treatments were the same as in orchard 1 plus an added one that included $60 \mathrm{~g}$ dazomet $/ \mathrm{m}^{2}$ applied with $150 \mathrm{~g}$ MAP in the planting hole. The fertilizer and mancozeb treatments were applied, as previously described, for the 27 Mar. planting. The formalin and dazomet were applied the previous September. Formalin was applied essentially as described above, whereas dazomet was surfaceapplied in 1-m-wide strips sufficiently long to cover the fourtree plots, rotovated to a $10-\mathrm{cm}$ depth, and packed with a roller. The experimental area, including these two fall-applied treatments, was then irrigated with overhead sprinklers for $0.5 \mathrm{~h}$ to apply $\approx 4 \mathrm{~mm}$ of water.

Insect, disease, weed, irrigation, and fertilizer practices were undertaken in the experimental plots, as in the main orchard, by the cooperating orchardists, according to standard commercial practices (British Columbia Ministry of Agriculture and Fisheries, 1989). Annual foliar applications of chelated $\mathrm{Zn}$ (both orchards) and chelated Mn (orchard 1) were made by the cooperating orchardists to ensure best growth of the trees.

For all experimental trees, trunk diameter was measured at a $0.3-\mathrm{m}$ height above ground level just after planting and each year in October. Annual trunk cross-sectional area increment was calculated from diameter measurements.

In mid-July of each of the first three (orchard 2) or four (orchard 1) growing seasons, composite leaf samples consisting of 30 leaves from the mid-third portion of extension shoots were obtained from each experimental plot. In orchard 1, only insufficient leaf material could be obtained from single-tree plots, so a composite leaf sample was collected per treatment (three leaves per each of 10 trees) in the first growing season. In the second growing season, treatment trees were paired (15 leaves per each of two trees, five replicates). All samples were ovendried at $65 \mathrm{C}$ and ground in a stainless steel mill. A $250-\mathrm{mg}$ subsample was digested for $0.75 \mathrm{~h}$ on a block digester at $350 \mathrm{C}$ in a 5-ml solution containing $1.9 \mathrm{~g} \mathrm{~K}_{2} \mathrm{SO}_{4}$ and $40 \mathrm{mg} \mathrm{HgO}$. After digestion, the cooled samples were diluted to $75-\mathrm{ml}$ volume with deionized water. Phosphorus was determined with the autoanalyzer method involving the formation of a phosphomolybdenum blue complex, while $\mathrm{N}$ was determined by calorimetric methods involving the formation of an ammoniumsalicylate complex (Technicon Autoanalyzer II Industrial Method no. 334-74 A/A; Technicon, Elmsford, N.Y. ). One-gram samples were also dry-ashed at $475 \mathrm{C}$ and dissolved in $0.5 \mathrm{M} \mathrm{HCI}$. Atomic absorption spectrophotometry was used to measure $\mathrm{Mn}$, $\mathrm{Zn}$, and $\mathrm{Fe}$. An aliquot of the original acid solutions was diluted with $0.65 \%$ lanthanum in $0.5 \mathrm{M} \mathrm{HCl}$ before analysis for $\mathrm{Ca}$, $\mathrm{Mg}$, and K. During leaf sampling, commencing in the 3rd year for orchard 1 and the 2nd year for orchard 2, the number of fruit was counted on each tree.

Analysis of variance was performed on all growth and leaf analysis data according to the orchard experimental design.

\section{Results and Discussion}

MAP fertilization plus formalin disinfection of the planting hole significantly increased tree size as indicated by larger trunk cross-sectional areas at the end of the first growing season in orchard 1 (Table 1). By the end of the 2nd year, all plantinghole treatments including formalin + MAP, mancozeb + MAP, and MAP alone resulted in significantly larger trees, but formalin + MAP was superior to other treatments. However, in the third and fourth growing seasons, there was a relative improvement in the growth rate of the control ( $\mathrm{N}$ only) trees, although after 4 years, trees in formalin + MAP-treated planting holes were still larger than the others. Increased initial tree size resulted in significantly more fruit in years 3 and 4 for the formalin + MAP treatment, relative to the control or MAP alone. These trees were 2. 1-fold larger by year 4 than control trees and had produced 3. 1-fold more fruit in the third and fourth growing seasons.

In orchard 2, MAP + soil disinfection treatments involving formalin and dazomet resulted in significantly larger trees by the end of the second growing season despite the formalin + MAP-treated trees having an initial smaller diameter at planting (Table 1). The effect of dazomet + MAP on tree size was apparent at the end of year 1 . The formalin and mancozebtreated trees fruited more in year 2 than those treated with $\mathrm{N}$ alone. As in orchard 1 , the relative growth of control trees increased in later years, but in orchard 2, control tree growth was greater so that by year 3 there were no significant differences in trunk diameter increments, although mancozeb + MAP treated trees yielded more fruit than the control.

Initial growth and fruiting responses to MAP plus soil disinfection were measured in the field for both orchards, although as suggested previously by the greenhouse data, growth responses were less pronounced in the second orchard. The response to formalin + MAP is consistent with growth responses to formaldehyde treatment alone measured in orchards in England (Sewell and White, 1979) and Washington state (Covey et al., 1984). The data from British Columbia sites would also suggest that other broad-spectrum biocides, including mancozeb and dazomet, with MAP can be effective, although, as in orchard 1, differences can occur between biocides. Greenhouse tests can give an early indication of differences in the effectiveness of various biocides. Planting-hole MAP fertilization improved initial tree growth relative to $\mathrm{N}$ only in orchard 1, despite high initial extractable soil $\mathrm{P}$ values at this site. This observation suggests that extractable soil P methods, as developed for annual crops, do not predict MAP needs of establishing fruit trees. However, growth responses from MAP were not as large as when used in combination with biocides in either orchard. Although there were no field tests using biocides alone, pot testing in British Columbia suggested such treatments were not as effective as when used in combination with MAP (Slykhuis and $\mathrm{Li}, 1985)$. The use of planting-hole $\mathrm{P}$ fertilization in combination with some form of soil disinfection seems to be a desirable strategy since high $\mathrm{P}$ availability is known to increase the initial root length and improve the establishment of some woody perennials (Neilsen et al., 1990b). Also, a perceived disadvantage of destruction of potentially beneficial mycorrhizal fungus associations by fumigation (Lambert et al., 1979) may be lessened by the addition of $\mathrm{P}$, the acquisition of which is known to be a major nutritional advantage of mycorrhizal infection of fruit trees. This relationship may be especially important since efforts to use vesicular-arbuscular mycorrhiza to improve $\mathrm{P}$ nutrition and growth of fruit trees under nonsterilized 
Table 1. Mean annual increment of trunk cross-sectional area at a $0.3-\mathrm{m}$ height and number of fruit for apple trees replanted in old orchard soil and subjected to various planting-hole fertilization and soildisinfection treatments.

\begin{tabular}{|c|c|c|c|c|c|c|c|c|}
\hline \multirow{3}{*}{$\begin{array}{l}\text { Planting-hole } \\
\text { treatment }\end{array}$} & \multicolumn{5}{|c|}{ Trunk cross-sectional area $\left(\mathrm{mm}^{2}\right)$} & \multirow{2}{*}{\multicolumn{3}{|c|}{$\frac{\text { Fruit no./tree }}{\text { Year }}$}} \\
\hline & \multirow[b]{2}{*}{ Initial } & \multicolumn{4}{|c|}{ Year } & & & \\
\hline & & 1 & 2 & 3 & 4 & 2 & 3 & 4 \\
\hline \multicolumn{9}{|l|}{ Orchard $1^{y}$} \\
\hline $34 \mathrm{~N}-0 \mathrm{P}-0 \mathrm{~K}$ (Control) & $58 \mathrm{a}$ & $128 \mathrm{~b}$ & $282 \mathrm{c}$ & $482 \mathrm{c}$ & $843 \mathrm{~b}$ & nc & $7.2 \mathrm{~b}$ & $12.1 \mathrm{c}$ \\
\hline $11 \mathrm{~N}-24 \mathrm{P}-0 \mathrm{~K}$ (MAP) & $57 \mathrm{a}$ & $155 \mathrm{~b}$ & $396 \mathrm{~b}$ & $631 \mathrm{bc}$ & $1025 \mathrm{~b}$ & nc & $11.6 \mathrm{~b}$ & $19.5 \mathrm{bc}$ \\
\hline Formalin + MAP & $55 \mathrm{a}$ & $237 \mathrm{a}$ & $761 \mathrm{a}$ & 1179 a & $1766 \mathrm{a}$ & nc & $26.8 \mathrm{a}$ & $33.9 \mathrm{a}$ \\
\hline Mancozeb + MAP & $52 \mathrm{a}$ & $148 \mathrm{~b}$ & $471 \mathrm{~b}$ & $675 \mathrm{~b}$ & $1121 \mathrm{~b}$ & $\mathrm{nc}$ & $11.8 \mathrm{~b}$ & $28.1 \mathrm{ab}$ \\
\hline Significance & NS & $* * * *$ & $* * * *$ & $* * * *$ & $* * * *$ & & $* * * *$ & $*$ \\
\hline \multicolumn{9}{|l|}{ Orchard $2^{y}$} \\
\hline $34 \mathrm{~N}-0 \mathrm{P}-0 \mathrm{~K}$ (Control) & $106 \mathbf{a}$ & $185 \mathrm{bc}$ & $330 \mathrm{~cd}$ & $509 a$ & & $0.2 \mathrm{c}$ & $23.6 \mathrm{~b}$ & \\
\hline $11 \mathrm{~N}-24 \mathrm{P}-0 \mathrm{~K}(\mathrm{MAP})$ & $106 \mathrm{a}$ & $209 \mathrm{abc}$ & $368 \mathrm{bcd}$ & $559 \mathrm{a}$ & & $1.5 \mathrm{bc}$ & $24.2 \mathrm{~b}$ & \\
\hline Formalin + MAP & $93 \mathrm{~b}$ & $223 \mathrm{abc}$ & $435 \mathrm{ab}$ & $559 \mathrm{a}$ & & $4.9 \mathrm{a}$ & $35.2 \mathrm{ab}$ & \\
\hline Mancozeb + MAP & $108 \mathrm{a}$ & $230 \mathrm{ab}$ & $404 \mathrm{abc}$ & $558 \mathrm{a}$ & & $4.5 \mathrm{ab}$ & $43.3 \mathrm{a}$ & \\
\hline Dazomet + MAP & 103 a & $251 \mathrm{a}$ & $464 \mathrm{a}$ & $658 \mathrm{a}$ & & $2.8 \mathrm{abc}$ & $33.0 \mathrm{ab}$ & \\
\hline Significance & $* *$ & $*$ & $* *$ & NS & & * & $*$ & \\
\hline
\end{tabular}

${ }^{\mathrm{x}}$ Fruit not counted this year.

y34N-0P-0K, $48.5 \mathrm{~g}$; MAP, $150 \mathrm{~g}$; formalin, $200 \mathrm{ml}$; mancozeb, $30 \mathrm{~g}$; dazomet, $60 \mathrm{~g} \cdot \mathrm{m}^{-2}$.

$*, * *, * * *, \mathrm{NS}$ Mean separation in columns in the same orchard at $P=0.05,0.01$, or 0.0001 or nonsignificant, respectively. Data presented are means of 10 (orchard 1) or 16 trees (orchard 2).

field conditions has met with limited success (Plenchette et al., 1981).

For both orchards, there were nutritional consequences of planting-hole treatments. In orchard 1 , leaf N, P, K, Ca, and $\mathrm{Mg}$ were significantly affected in some years (Table 2). It was not possible to monitor effects of treatments on leaf $\mathrm{Zn}$ and $\mathrm{Mn}$ concentration due to contamination of leaves by the foliar application of these nutrients by the cooperating orchardist. Leaf $\mathrm{N}$ concentration was generally higher than suggested as "normal" for all treatments throughout the 4-year study, with the most vigorous trees (formalin + MAP) having the lowest leaf $\mathrm{N}$ in years 2 and 3. Leaf $\mathrm{P}$ concentrations declined from high first-year values during the period of the study, with a significant increase associated with the mancozeb + MAP treatment in year 2. Significant reductions in leaf $\mathrm{K}$ in years 2-4 coincided with treatments with increased number of fruit. In contrast, leaf $\mathrm{Ca}$ concentration was increased above control trees in years 2 and 4 by all planting-hole treatments, while leaf $\mathrm{Mg}$ concentration increased in year 2 for the two disinfectant + MAP treatments. Despite this occasional increase in leaf $\mathrm{Mg}, \mathrm{Mg}$ nutrition was generally marginal in this orchard, with mild Mg deficiency symptoms observed on the basal leaves of current year's extension growth in all treatments in year 2. The apparent inadequate $\mathrm{Mg}$-supplying capacity of this orchard soil was not overcome by any of the planting-hole treatments.

In orchard 2, there were fewer nutritional consequences of the various planting-hole treatments (Table 3). All treatments involving the application of MAP resulted in large increases in leaf $\mathrm{P}$ concentration in the first year. These differences were reduced, but significant, in year 2 but had disappeared by year 3. All planting-hole MAP applications increased leaf Mn concentration in the first growing season, likely a consequence of more severe acidification of planting-hole soil resulting from the application of MAP, which contained all its $\mathrm{N}$ fertilizer in the acid-producing $\mathrm{NH}_{4}-\mathrm{N}$ form. The treatment involving application of a Mn-containing fungicide (mancozeb) + MAP resulted in highest first-year leaf Mn concentrations and also significant increases in leaf Mn relative to control trees in years 2 and 3. Leaf $\mathrm{N}$ concentration was significantly increased in year 1 for the mancozeb + MAP treatment, although all treatments had adequate $\mathrm{N}$ and the increase did not persist beyond year 1 (data not shown).

Table 2. Mean leaf $\mathrm{N}, \mathrm{P}, \mathrm{K}, \mathrm{Ca}$, and $\mathrm{Mg}$ concentrations (all as percent dry weight) as affected by planting-hole treatments, years 1-4 in orchard 1.

\begin{tabular}{|c|c|c|c|c|c|c|c|c|c|c|c|c|c|c|c|c|c|c|c|c|}
\hline \multirow{3}{*}{$\begin{array}{l}\text { Planting-hole } \\
\text { treatment }{ }^{y}\end{array}$} & \multicolumn{4}{|c|}{ Leaf $N$} & \multicolumn{4}{|c|}{ Leaf $P$} & \multicolumn{4}{|c|}{ Leak K } & \multicolumn{4}{|c|}{ Leaf $\mathrm{Ca}$} & \multicolumn{4}{|c|}{ Leaf $\mathrm{Mg}$} \\
\hline & \multicolumn{20}{|c|}{ Year } \\
\hline & 1 & 2 & 3 & 4 & 1 & 2 & 3 & 4 & 1 & 2 & 3 & 4 & 1 & 2 & 3 & 4 & 1 & 2 & 3 & 4 \\
\hline $\begin{array}{c}34 \mathrm{~N}-0 \mathrm{P}-0 \mathrm{~K} \\
(\text { Control) } \\
11 \mathrm{~N}-24 \mathrm{P}-0 \mathrm{~K}\end{array}$ & 2.84 & $2.63 \mathrm{ab}$ & $2.90 \mathrm{ab}$ & $3.05 \mathrm{a}$ & 0.15 & $0.18 \mathrm{~b}$ & $0.18 \mathrm{a}$ & $0.17 \mathrm{a}$ & 2.26 & $2.40 \mathrm{a}$ & $2.15 \mathrm{a}$ & $1.82 \mathrm{a}$ & 0.92 & $0.70 \mathrm{~b}$ & $0.66 \mathrm{a}$ & $0.76 \mathrm{~b}$ & 0.21 & $0.15 \mathrm{~b}$ & $0.22 \mathrm{a}$ & $0.18 \mathrm{a}$ \\
\hline $\begin{array}{l}\text { (MAP) } \\
\text { Formalin + }\end{array}$ & 3.17 & $2.68 \mathrm{ab}$ & $3.00 \mathrm{a}$ & $3.15 \mathrm{a}$ & 0.26 & $0.20 \mathrm{ab}$ & $0.19 \mathrm{a}$ & $0.18 \mathrm{a}$ & 2.28 & $2.25 \mathrm{ab}$ & $1.95 \mathrm{~b}$ & $1.67 \mathrm{~b}$ & 0.89 & $0.90 \mathrm{a}$ & $0.75 \mathrm{a}$ & $0.95 \mathrm{a}$ & 0.23 & $0.15 \mathrm{~b}$ & $0.23 \mathrm{a}$ & $0.21 \mathrm{a}$ \\
\hline $\begin{array}{c}\text { MAP } \\
\text { Mancozeb + }\end{array}$ & 3.20 & $2.51 \mathrm{~b}$ & $2.79 \mathrm{~b}$ & $2.92 \mathrm{a}$ & 0.24 & $0.18 \mathrm{~b}$ & $0.18 \mathrm{a}$ & $0.17 \mathrm{a}$ & 2.27 & $1.93 \mathrm{c}$ & $1.90 \mathrm{~b}$ & $1.62 \mathrm{~b}$ & 1.02 & $0.94 \mathrm{a}$ & $0.65 \mathrm{a}$ & $0.93 \mathrm{a}$ & 0.19 & $0.18 \mathrm{a}$ & $0.22 \mathrm{a}$ & $0.22 \mathrm{a}$ \\
\hline $\begin{array}{l}\text { MAP } \\
\text { Significance }\end{array}$ & 3.36 & $2.82 \mathrm{a}$ & $\underset{*}{2.88} \mathrm{ab}$ & $\begin{array}{l}2.99 \mathrm{a} \\
\mathrm{NS}\end{array}$ & 0.32 & $0.21 \mathrm{a}$ & $\begin{array}{c}0.19 \mathrm{a} \\
\mathrm{NS}\end{array}$ & $\begin{array}{l}0.18 \mathrm{a} \\
\text { NS }\end{array}$ & 2.28 & $\underset{* *}{2.13 b}$ & $1.93 \mathrm{~b}$ & $1.64 \mathrm{~b}$ & 0.76 & $\begin{array}{c}0.89 \mathrm{a} \\
*\end{array}$ & $\begin{array}{c}0.68 \mathrm{a} \\
\text { NS }\end{array}$ & $0.89 \mathrm{a}$ & 0.21 & $\underset{* *}{0.18} \mathrm{a}$ & $\begin{array}{c}0.23 \mathrm{a} \\
\text { NS }\end{array}$ & $\begin{array}{c}0.20 \mathrm{a} \\
\text { NS }\end{array}$ \\
\hline
\end{tabular}

${ }^{2}$ Composite sample per treatment in year 1 .

${ }^{\mathrm{y}} 34 \mathrm{~N}-0 \mathrm{P}-0 \mathrm{~K}, 48.5 \mathrm{~g}$; MAP, $150 \mathrm{~g}$; formalin, $200 \mathrm{ml}$; mancozeb, $30 \mathrm{~g}$.

*,**,Ns Mean separation in columns at $P=0.05$ or 0.01 or nonsignificant, respectively. Data presented are the means of 10 samples, except year 1 (single sample) and year 2 (five samples). 
Table 3. Mean leaf $\mathrm{P}$ and $\mathrm{Mn}$ concentrations as affected by planting-hole treatments, years $1-3$ in orchard 2 .

\begin{tabular}{|c|c|c|c|c|c|c|}
\hline \multirow{3}{*}{$\begin{array}{l}\text { Planting-hole } \\
\text { treatment }^{\mathbf{2}}\end{array}$} & \multicolumn{3}{|c|}{ Leaf P (\% dry wt) } & \multicolumn{3}{|c|}{ Leaf $\mathrm{Mn}\left(\mu \mathrm{g} \cdot \mathrm{g}^{-1}\right.$ dry wt) } \\
\hline & \multicolumn{6}{|c|}{ Year } \\
\hline & 1 & 2 & 3 & 1 & 2 & 3 \\
\hline $34 \mathrm{~N}-0 \mathrm{P}-0 \mathrm{~K}$ (Control) & $0.17 \mathrm{c}$ & $0.18 \mathrm{c}$ & 0.19 & $66 \mathrm{~d}$ & $49 \mathrm{c}$ & $67 \mathrm{c}$ \\
\hline $11 \mathrm{~N}-24 \mathrm{P}-0 \mathrm{~K}$ (MAP) & $0.29 \mathrm{~b}$ & $0.22 \mathrm{ab}$ & 0.20 & $100 \mathrm{c}$ & $59 \mathrm{bc}$ & $80 \mathrm{bc}$ \\
\hline Formalin + MAP & $0.28 \mathrm{~b}$ & $0.20 \mathrm{~b}$ & 0.18 & $125 \mathrm{~b}$ & $66 \mathrm{bc}$ & $82 \mathrm{bc}$ \\
\hline Mancozeb + MAP & 0.37 a & $0.22 \mathrm{ab}$ & 0.20 & 176 a & $128 \mathrm{a}$ & $122 \mathrm{a}$ \\
\hline Dazomet + MAP & $0.27 \mathrm{~b}$ & $0.20 \mathrm{~b}$ & 0.20 & $129 \mathrm{~b}$ & $70 \mathrm{bc}$ & $88 \mathrm{bc}$ \\
\hline Significance & $* *$ & $* * *$ & NS & $* * *$ & $* * * *$ & $* *$ \\
\hline
\end{tabular}

Potentially, the most important nutritional responses to the planting-hole treatments were those involving P. The application of high rates of MAP fertilizer in the planting hole resulted in first-year leaf $\mathrm{P}$ concentrations in both orchards much above values measured throughout the study for control trees. Firstyear midterminal leaf $\mathrm{P}$ concentrations in the $0.25 \%$ to $0.30 \%$ range have previously been associated with increased blossoming and fruit set in the 2nd year for apple trees on dwarfing rootstock planted in soils not suffering from replant problems (Neilsen et al., 1990a). The early yield data from these two replant problem orchards indicate that high soil MAP and some degree of initial soil disinfection were required to accelerate early fruiting. The subsequent rapid decline in leaf $\mathrm{P}$ concentration for MAP-fertilized treatments is consistent with reduced availability of $\mathrm{P}$ applied to soil in the immediate planting hole or a close coupling between tree growth and phosphate absorption rate, as hypothesized in Australia (Taylor, 1975). The apparent acidification of planting-hole soil and the addition of a Mn-containing fungicide, which increased leaf Mn concentration in one of the orchards, presented no serious problems for the young trees, with leaf Mn concentrations decreasing after the first year, except where Mn was also applied to the soil. The high level of Mn is unlikely to be a major problem unless original soil $\mathrm{pH}$ was lower and cultivars susceptible to Mn toxicity were planted, as observed for internal bark necrosis of 'Delicious' apple trees (Fisher et al., 1977). The reported changes in leaf $\mathrm{N}, \mathrm{Ca}$, and $\mathrm{Mg}$ did not alter the nutrient status of the trees, whereas the observed decreases in leaf $\mathrm{K}$ presumably were a consequence of a desirable increase in initial fruiting.

In summary, improvements in initial growth and subsequent early fruiting were measured in two apple orchards suffering from replant problems of differing severity. Planting-hole applications of MAP plus some degree of broad-spectrum soil disinfection, as achieved here by formalin, dazomet, or mancozeb, improved initial growth. Nutritional implications of these treatments included a large increase in leaf $\mathrm{P}$ concentration, which declined after year 1 , but also a potentially detrimental short-term leaf Mn concentration increase associated with acidification of the planting-hole soil or incorporation of a Mncontaining fungicide into the planting-hole soil. The results in these two orchards were generally predicted by preliminary greenhouse test results. However, success is not guaranteed merely by application of the best pot test treatment. Failure to respond to planting-hole treatments has been observed in some local field trials and has been attributed to other site and orchard management limitations, including moisture stress, excessive weed competition, poor rootstock quality, excessive planting-hole MAP application, and high or low soil pH (Neilsen, 1988).

\section{Literature Cited}

Benson, N.R. 1976. Retardation of apple tree growth by soil arsenic residues. J. Amer. Soc. Hort. Sci. 101:251-253.

British Columbia Ministry of Agriculture and Fisheries. 1989. Tree fruit production guide for interior districts. Country Life, Surrey, B.C.

Covey, R. P., B.L. Koch, H.J. Larsen, and W.A. Haglund. 1984. Control of replant disease with formaldehyde in Washington. Plant Dis. 68:981-983.

Fisher, A. G., G.W. -Eaton, and S.W. Porritt. 1977. Internal bark necrosis of Delicious apple in relation to soil pH and leaf manganese. Can. J. Plant Sci. 57:297299.

Hoestra, H. 1968. Replant diseases of apple in the Netherlands. Med. Lanb. Wageningen, 68-13.

Hoyt, P.B. and G.H. Neilsen. 1985. Effects of soil pH and associated cations on growth of apple trees planted in old orchard soil. Plant \& Soil 86:395-401.

Kelley, C.C. and R.H. Spilsbury. 1949. Soil survey of the Okanagan and Similkameen Valleys. British Columbia Dept. Agr. and Dominion Dept. Agr., Ottawa, Ont.

Koch, B. L., R.P. Covey, Jr., and W. Haglund. 1980. Effect of soil fumigation on the early growth and production of 'Delicious' apple trees. J. Amer. Soc. Hort. Sci. 105:887-890.

Lambert, D. M., R.F. Stouffer, and H. Cole, Jr. 1979. Stunting of peach seedlings following soil fumigation. J. Amer. Soc. Hort. Sci. 104:433-435.

Merwin, LA. and W.C. Stiles. 1989. Root-lesion nematodes, potassium deficiency, and prior cover crops as factors in apple replant disease. J. Amer. Soc. Hort. Sci. 114:724-728.

Neilsen, G.H. 1988. Phosphorus research on tree fruits in British Columbia, Canada. Proc. Washington State Hort. Assn. 84th Annu. Mtg. p. 230-232.

Neilsen, G. H., E.J. Hogue, and P. Parchomchuk. 1990a. Flowering of apple trees in the second year is increased by first year P fertilization. HortScience 25: 12471250

Neilsen, G. H., D. Neilsen, and D. Atkinson. 1990b. Top and root growth and nutrient absorption of Prunus avium L. at two soil $\mathrm{pH}$ and $\mathrm{P}$ levels. Plant \& Soil 121:137-144.

Plenchette, C., V. Furlan, and J.A. Fortin. 1981. Growth stimulation of apple trees in unsterilized soil under field conditions with VA mycorrhiza inoculation. Can. J. Bot. 59:2003-2008

Sewell, G.W.F. and G.C. White. 1979. The effects of formalin and other soil treatments on the replant disease of apple. J. Hort. Sci. 54:333-335.

Sewell, G.W.F., D.A. Preece, and R.F. Elsey. 1988. Apple replant disease: The influence of soil phosphorus and other factors on the growth responses of apple seedlings to soil fumigation with chloropicrin. Ann. Appl Biol 113:605-15.

Slykhuis, J.T. and T.S.C. Li. 1985. Responses of apple seedlings to biocides and phosphate fertilizers in orchard soils in British Columbia. Can. J. Plant Pathol 7:294-301

Taylor, B.K. 1975. Response of newly planted peach and apple trees to superphosphate. Austral J. Agr. Res. 26:521-528.

Traquair, J.A. 1984. Etiology and control of orchard replant problems: A review. Can. J. Plant Pathol. 6:54-62.

Yadava, U.L. and S.L. Doud. 1980. The short fife and replant problems of deciduous fruit trees. Hort. Rev. 2:1-116. 